\title{
Pelaksanaan Pelayanan Gawat Darurat Bagi Peserta BPJS Kesehatan Di Rumah Sakit Umum Daerah Ratu Aji Putri Botung Ditinjau Dari Keputusan Menteri Kesehatan Nomor 856/Menkes/Sk/Ix/2009 Tentang Standar Instalasi Gawat Darurat (IGD) Rumah Sakit
}

\author{
Jansje Grace Makisurat; Y. Budi Sarwo dan Daniel Budi Wibowo \\ email:mjansegrace@yahoo.com \\ Master of Law Science \\ Concentration of Health Law \\ Soegijapranata Catholic University of Semarang
}

\begin{abstract}
Indonesian Hospital is a health service facility to support the implementation of health efforts. RSUD in collaboration with BPJS often accepts patients not according to the criteria of emergency criteria. This study aims to determine the implementation of emergency services for participants JKN Health in IGD and Decree of the Minister of Health of the Republic of Indonesia No. 856 / Menkes / SK / IX / 2009 on Emergency Installation Standards.
\end{abstract}

This research was conducted at the General Hospital of Ratu Aji Putri Botung Area. This research uses sociological juridical approach method with analytical descriptive specification. The data used are primary and secondary data through observation and interview 60 respondents to Head of Health Service, Head of Medical Service, Head of Room of IGD, Head of Unit of Integrated Health Insurance, and manager of BPJS. Data of research result is analyzed by using qualitative method.

The results showed that JKN participants were aware of the service flow (32\%), were aware of referral service flow (20\%), were aware of the emergency's criteria (28\%) and were aware of the JKN participants' rights and obligations (48\%). It is because lack of understanding on JKN regulation that become obstacle to access IGD services. Patients who have applied service at the Regional Public Hospital's emergency unit were served according to the service flow regulated by BPJS. The Triage method was conducted to patients who applied for service at the Emergency unit to sort out which are emergency cases and which are not. RSUD RAPB has not implemented KMK Number 856 / Menkes / SK / IX / 2009 on Hospital's Emergency Unit Standard was not properly implemented in the hospital includes the absence of legal sanction and the absence of a clear regulation at the regional level, therefore the legalization and modification the regulation is required for the legal product to be effective. Budget support from the government and local government is needed for optimal health service delivery in RSUD RAPB. Supervision and guidance from the Department of Health is needed as a control in ensuring that the regulations are being properly implemented. Intensive socialization by BPJS is required in order to make changes in the general community behavior so that people would understand and obey the rules as JKN participants.

Keywords: Hospital, Emergency, BPJS. 


\section{PENDAHULUAN}

\section{A. Latar Belakang}

Pada pelayanan kesehatan dengan menggunakan fasilitas kesehatan yang bekerjasama dengan BPJS, khususnya pada pelayanan kegawatdaruratan diberikan dengan kriteria khusus. Kriteria kegawatdaruratan yang dapat diklaim pada pembiayaan BPJS ditetapkan berdasarkan kriteria kegawatdaruratan yang telah dirumuskan oleh BPJS. ${ }^{1}$

Pelayanan sepatutnya dapat memenuhi kepuasan objek yang dilayani, karena tingkat kepuasan objek yang dilayani menjadi salah satu tolok ukur bahwa pelayanan yang diberikan telah memenuhi standar normatif yang diharapkan masyarakat. Pelayanan merupakan proses pemenuhan kebutuhan masyarakat secara langsung yang dilakukan sehingga masyarakat memperoleh kepuasan. Terlebih lagi di era pasca modern dimana fasilitas kesehatan dan kompetensi sumber daya kesehatan sudah semakin maju tentunya diharapkan mutu pelayanan menjadi semakin baik. ${ }^{2}$

Pembangunan kesehatan pada periode 2015-2019 adalah Program Indonesia Sehat. Program Indonesia Sehat dilaksanakan dengan 3 pilar utama yaitu: paradigma sehat, penguatan pelayanan kesehatan dan jaminan kesehatan nasional. 3 Jaminan Kesehatan Nasional (JKN) merupakan bagian dari Sistem Jaminan Sosial Nasional (SJSN) yang diselenggarakan dengan menggunakan mekanisme asuransi kesehatan sosial. Tujuannya untuk memenuhi kebutuhan dasar kesehatan masyarakat yang layak, yang diberikan kepada setiap orang yang telah membayar iuran atau iurannya dibayar oleh pemerintah.Jaminan kesehatan merupakan jaminan berupa perlindungan kesehatan agar peserta memperoleh manfaat pemeliharaan kesehatan dan perlindungan dalam memenuhi kebutuhan dasar kesehatan.Jaminan Kesehatan Nasional (JKN) diharapkan sebagai akses dan kemampuan membayar masyarakat terhadap pelayanan kesehatan, sehingga status kesehatan menjadi optimal.

Rumah sakit sebagai salah satu fasilitas pelayanan kesehatan merupakan bagian dari sumber daya kesehatan yang sangat diperlukan dalam mendukung penyelenggaraan upaya kesehatan. ${ }^{4}$ Rumah sakit adalah suatu organisasi yang sifatnya kompleks, kini dengan perkembangan zaman dan teknologi makin lama makin bertambah kompleks pula bertambah padat modal, padat tenaga, padat teknologi dan padat persoalan dalam bidang antara lain, hukum, ekonomi, etik, HAM, teknologi dan lain-lain. ${ }^{5}$

Rumah sakit mempunyai tugas memberikan pelayanan kesehatan perorangan yang paripurna. Artinya, setiap kegiatan pelayanan kesehatan yang diberikan oleh tenaga

\footnotetext{
${ }^{1}$ Anonim, Panduan Praktik Tentang Kepersertaan yang Diselenggrakan Oleh BPJS Kesehatan Berdasarkan Regulasi yang sudah Terbit, hal.22.

${ }^{2}$ Moha Anugrah Aditya, 2016, Ekonomi Politik Kesehatan Indonesia: Refleksi Pemikiran dan Kebijakan Kesehatan, Jakarta: PT. Wahana Semesta Intermedia, hal. 1

${ }^{3}$ Anonim, 2015, RencanaStrategisKementerianKesehatanTahun 2015-2019

${ }^{4}$ Rosihan Adhani, 2016, Mengelola Rumah Sakit, Banjarmasin: Lambung Mangkurat University Press, hal. 16.

5 Amir llyas, Pertanggungjawaban Pidana Dokter dalam Malpraktik Medik di Rumah Sakit, Yogyakarta: Rangkang Educatio, hal. 17.
} 
kesehatan untuk memelihara dan meningkatkan kesehatan, mencegah dan menyembuhkan penyakit, dan memulihkan kesehatan. ${ }^{6}$

Kementerian Kesehatan telah mengeluarkan Keputusan Menteri Kesehatan Nomor 856/Menkes/SK/IX/2009 tentang Standar Instalasi Gawat Darurat Rumah Sakit sebagai pedoman pemerintah daerah dalam menyediakan IGD rumah sakit yang terstandar. Standar Instalasi Gawat Darurat yang dimaksudkan oleh peraturan ini adalah fisik bangunan,peralatan yang harus dimiliki sesuai tipe rumah sakit, tenaga kesehatan sesuai tipe rumah sakit dan diagnosa gawat darurat.

RSUD Ratu Aji Putri Botung merupakan satu-satunya rumah sakit daerah yang ada di Kabupaten Penajam Paser Utara dan merupakan rumah sakit tipe $C$ yang telah berdiri sejak tahun 2007 telah memiliki berbagai fasilitas dalam menjalankan fungsinya termasuk IGD. Instalasi Gawat Darurat RSUD Ratu Aji Putri Botung merupakan salah satu pusat pelayanan kesehatan yang memberikan pelayanan kesehatan kepada masyarakat selama 24 jam dan 7 hari dalam seminggu.

Hasil prasurvei yang dilakukan peneliti didapatkan data jumlah kunjungan pasien di IGD tahun 2016 sebanyak 11.704 dengan kasus gawat darurat (true emergency) sebanyak $25 \%$ dan kasus bukan gawat darurat (false emergency) ada $75 \%$. Dari data diatas peneliti melihat masih banyak kasus bukan gawat darurat (false emergency) yang dating dan ditangani oleh IGD RSUD Ratu Aji Putri Botung. Hal ini didukung juga dengan data 10 besar penyakit yang ditangani di IGD RSUD adalah: 1. Dispepsia; 2. Vulnus; 3.Febris; 4. Inpartu; 5.ISPA; 6. DHF; 7. GEA; 8. Hipertensi; 9. Abdominal pain; 10. Dispnea. Disini jelas terlihat bahwa masih banyak kasus rawat jalan yang dilayani di IGD.

Banyaknya kasus bukan gawat darurat yang datangke IGD RSUD mengakibatkan RSUD mengalami kesulitan dalam melayani kunjungan pasien yang tidak seharusnya ditangani di fasilitas ini. Kesulitan yang dihadapi IGD RSUD Ratu Aji Putri Botung adalah saat mengatakan kepada pasien yang datang ke IGD bahwa jenis penyakit pasien tidak termasuk kategori gawat darurat sehingga karena tidak dijamin maka pasien akan diberlakukan sebagai pasien umum dimana konsekuensinya adalah pasien harus membayar semua biaya pelayanan yang sudah diterima. Hal demikian sering menjadi pemicu keributan dengan pasien, keluarga pasien, masyarakat, LSM dan beberapa pejabat di daerah yang berujung pada pemberitaan yang kurang sedap tentang rumah sakit di berbagai media.

Dari latarbelakang ini maka peneliti tertarik untuk melakukan pendalaman masalah diatas dengan memberi judul: "Pelaksanaan Pelayanan Gawat Darurat Bagi Peserta BPJS Kesehatan Di Rumah Sakit Umum Daerah Ratu Aji Putri Botung ditinjau dari Keputusan Menteri Kesehatan Nomor 856/Menkes/SK/Ix/2009 Tentang Standar Instalasi Gawat Darurat (IGD) Rumah Sakit".

${ }^{6}$ Rosihan Adhani, op.cit., hal. 22. 


\section{B. Rumusan Masalah}

Berdasarkan uraian latar belakang di atas, maka dalam penulisan tesis ini dirumuskan beberapa rumusan masalah, yaitu:

1. Bagaimanakah ketentuan pelayanan gawat darurat bagi peserta JKN di Instalasi Gawat Darurat RSUD Ratu Aji Putri Botung?

2. Bagaimanakah pelaksanaan Keputusan Menteri Kesehatan Republik Indonesia Nomor 856/Menkes/SK/IX/2009 tentang Standar Instalasi Gawat Darurat (IGD) Rumah Sakit di RSUD Ratu Aji Putri Botung?

3. Faktor-faktor apa saja yang menghambat dalam penerapan Keputusan Menteri Kesehatan Republik Indonesia Nomor 856/Menkes/SK/IX/2009 tentang Standar IGD Rumah Sakit pada IGD RSUD Ratu Aji Putri Botung?

\section{Metode Penelitian}

\section{Metode Pendekatan}

Metode pendekatan yang digunakan peneliti adalah metode pendekatan yuridis empiris. Penelitian yuridis empiris adalah penelitian lapangan mengenai pelaksanaan atau implementasi ketentuan hukum normatif secara nyata pada setiap peristiwa hukum tertentu yang terjadi dalam masyarakat.7 Penelitian yuridis empiris merupakan penelitian lapangan (penelitian terhadap data primer), yaitu suatu penelitian yang meneliti peraturan-peraturan hukum yang kemudian digabungkan dengan data dan perilaku di masyarakat. ${ }^{8}$ Penelitian ini menggunakan pendekatan empiris untuk mendapatkan gambaran tentang pelayanan gawat darurat dan penerapan criteria kegawatdaruratan bagi pasien peserta BPJS Kesehatan di Instalasi Gawat Darurat di RSUD Ratu Aji Putri Botung.

\section{Spesifikasi Penelitian}

Spesifikasi penilitian yang digunakan dalam penelitian ini adalah deskriptif analitis, yaitu penelitian yang membuat deskripsi atau gambaran mengenai masalah hukum tertentu di masyarakat yang sifatnya melaksanakan sampai mengklarifikasi hukum positif itu menjadi berbagai kategori hukum.

Jenis penelitian deskriptif yang digunakan pada penelitian ini dimaksudkan untuk memperoleh informasi mengenai pelaksanaan pelayanan kegawatdaruratan di IGD RSUD Ratu Aji Putri Botung berdasarkan bagi peserta BPJS Kesehatan.

\section{SubjekdanObjekPenelitian}

a. Dalam penelitian yang menjadi subjek penelitian adalah pasien peserta BPJS Kesehatan yang menggunakan fasilitas pelayanan kegawatdaruratan di Rumah Sakit Umum Daerah Penajam Paser Utara; Kepala ruangan IGD RSUD; Unit Jaminan Kesehatan Terpadu RSUD; Kepala Bidang Pelayanan Medik RSUD; dan Pengelola BPJS dan Kepala Dinas Kesehatan Kabupaten Penajam Paser Utara. Alasan pengambilan subjek karena subjek ini sangat tepat sebagai bahan penelitian karena mereka sebagai penguna dan pelaku secara langsung, sehingga hasil penelitian lebih objektif karena diharapkan subjek akan menjawab sesuai dengan pengalaman

\footnotetext{
${ }^{7}$ Abdulkadir Muhammad, 2004, Hukum dan Penelitian Hukum, Bandung: Citra Aditya Bakti, hal. 134.

${ }^{8}$ Soejono Soekanto, 2015, Pengantar Penelitian Hukum, Jakarta: Penerbit Universitas Indonesia, hal 52.
} 
mereka sendiri dan bukan berdasarkan informasi media elektronik atau cerita orang lain.

b. Dan yang menjadi objek penelitian adalah pelayanan kesehatan di Instalasi Gawat Darurat Rumah Sakit Umum Daerah Ratu Aji Putri Botung Kabupaten Penajam Paser Utara.

\section{Jenis Data}

Jenis data yang digunakan adalah data primer dan data sekunder, karena penelitian yuridis empiris.

a. Data Primer adalahdata yang diperoleh secara langsung dari sumber pertama yang terkait dengan permasalahan yang akan di bahas. ${ }^{9}$ Sumber data diperoleh dari lapangan secara langsung dengan wawancara, observasi, pengamatan dan menggunakan daftar pertanyaan.

b. Data sekunder adalah data yang diperoleh dengan mempelajari bahan-bahan pustaka yang berupa perundang-undangan dan literatur-literatur lain yang berhubungan dengan permasalahan yang dibahas. Data sekunder terdapat tiga bahan hukum, yaitu bahan hukum primer, bahan hukum sekunder dan bahan hukum tersier. ${ }^{10}$

\section{Metode Pengumpulan Data}

Metode pengumpulan data terdiri dari studi kepustakaan, pengamatan (observasi), wawancara (interview), dan penggunaan daftar pertanyaan (kuesioner). ${ }^{11}$ Dalam penelitian ini dilakukan melalui dua cara, yaitu penelitian kepustakaan dan penelitian lapangan.

a. Studi kepustakaan digunakan untuk mengumpulkan dan mempelajari, serta memahami data, teori-teori atau pendapat yang berhubungan dengan pokok permasalahan. Data yang diperoleh dari studi kepustakaan disebut data sekunder.

b. Penelitian lapangan adalah pengumpulan data secara langsung dimana peneliti menggunakan beberapa metode pengumpulan data, yaitu:

1) Metode Wawancara, dimana peneliti ingin menggali informasi yang lebih luas baik berupa pendapat maupun ide-ide dari berbagai pihak yang tekait dalam penelitian ini, yaitu :

a) Dinas Kesehatan Kabupaten Penajam Paser Utara;

b) Kepala ruangan IGD RSUD;

c) Ketua Unit Jaminan Kesehatan Terpadu RSUD;

d) Kepala Bidang Pelayanan Medik RSUD;

e) Pengelola BPJS Kabupaten Penajam Paser Utara.

f) Dua Dokter IGD RSUD

g) Empat Perawat (satu perawat merangkap menjadi kepala ruangan) IGD RSUD

h) 60 Pasien peserta JKN

\footnotetext{
${ }_{9}^{9}$ Amiruddin, 2006, Pengantar Metode Penelitian Hukum, Jakarta: PT Grafindo Persada, hal. 30. ${ }^{10}$ Soerjono Soekanto dan Sri Mamudji, 2003, Penelitian Hukum Normatif, Suatu Tinjauan Singkat, Jakarta: PT. Raja Grafindo Persada, hal. 13.

${ }^{11}$ Ronni Hanitijo Seomitro, 1994, Metodologi Penelitian Hukum dan Jurimetri, Jakarta: Ghalia Indonesia, hal.12.
} 
2) Metode Observasi, pengamatan dan pencatatan yang sistematis terhadap gejala-gejala yang diselidiki. Metode ini dilakukan untuk memperoleh data yang berkaitan dengan pelaksanaan pelayanan gawat darurat bagi pasien BPJS Kesehatan dan pelaksanaan Keputusan Menteri Kesehatan Nomor 856/Menkes/SK/X/2009 tentang Standar IGD Rumah Sakit. Bukti dari hasil observasi didokumentasikan oleh peneliti dalam bentuk cek list dan foto-foto yang berhubungan dengan perumusan masalah.

\section{Metode Analisis Data}

Adapun metode analisis data yang dipergunakan dalam penelitian ini adalah analisis kualitatif. Analisis kualitatif dalam penelitian menjabarkan data secara bermutu dalam kalimat yang teratur sehingga memudahkan pembahasan dan pemahaman. Analisis data yang digunakan adalah analisis Kualitatif, yaitu dengan cara menjelaskan dan menerangkan data dalam bentuk kalimat-kalimat yang disusun dengan pokok bahasan, tujuan dan konsep yang berkaitan dengan hal tersebut secara sistematis, kemudian dilakukan bahasan dan analisis kesimpulannyanya sebagai jawaban atas pokok bahasan yang dikemukankan dalam penelitian. ${ }^{12}$

\section{HASIL DAN PEMBAHASAN}

\section{A. Hasil Wawancara dengan Responden dan Narasumber}

Wawancara dalam penelitian ini dilakukan terhadap beberapa pejabat struktural dan petugas IGD terdiri dari Kepala Bidang Pelayanan Medik, Kepala Ruangan IGD, dua orang Dokter IGD, empat orang Paramedis IGD, Kepala Seksi Penyusunan Program. Dan pejabat diluar RSUD RAPB adalah Kepala Badan Perencanaan Pembangunan, Penelitian dan Pengembangan Kabupaten Penajam Paser Utara, Kepala Dinas Kesehatan Kabupaten Penajam Paser Utara dan Kepala Kantor BPJS Kabupaten Penajam Paser Utara.

\section{a. Wawancara dengan Peserta JKN}

Responden lain adalah pasien yang datang di IGD RSUD RAPB yang dipilih sebanyak 60 (enam puluh) orang. Responden adalah peserta JKN yang berobat di IGD. Pelaksanaan wawancara kepada responden dilakukan di berbagai waktu, ada yang pagi, siang, dan sore hari. Responden yang diwawancarai ada yang masih berada diruangan IGD namun ada juga yang sudah diruang rawat inap. Dibawah ini ditampilkan hasil hasil wawancara dengan responden pasien pengunjung IGD.

\footnotetext{
${ }_{12}$ Abdul, Kadir Muhammad, 2004, Hukum dan Penelitian Hukum, Cet. Ke-1, Bandung: PT. Citra
} Aditya Bakti, hal. 127. 
Tabel 3.1 Karakteristik Responden Peserta BPJS

\begin{tabular}{|l|c|c|}
\hline \multicolumn{1}{|c|}{ Keterangan } & \multicolumn{2}{|c|}{ Jumlah Responden } \\
\hline & $\mathrm{N}$ & $\%$ \\
\hline Umur & 1 & 1,6 \\
- <17 tahun & 42 & 70 \\
- 18-45 tahun & 17 & 28 \\
\hline - 45tahun & & \\
\hline Pendidikan & 15 & 25 \\
- SD & 17 & 28 \\
- SMP & 20 & 33 \\
- SMA/SMK & 8 & 13 \\
- DIII/S1 & & \\
\hline Peserta JKN & 26 & 43 \\
- Lama & 34 & 56 \\
- Baru & & \\
\hline Frekuensi ke IGD & 13 & 21 \\
- Pertama kali & 38 & 63 \\
- 2-4 kali & 9 & 15 \\
- > 4 kali & & \\
\hline Jam Berkunjung & 21 & 35 \\
- 08.00 - 12.00 & 39 & 65 \\
- 12.00 keatas &
\end{tabular}

Sumber: data primer diolah, 2017

Hasil penelitian menunjukan bahwa mayoritas responden berusia 18 - 45 tahun (67\%), dengan pendidikan terbanyak adalah SMA/SMK 33\%. Responden terbanyak adalah peserta JKN yang baru yaitu 56\%, yang berkunjung ke IGD terbanyak adalah 2-4 kali disepanjang tahun 2017 ini.

Tabel 3.2 Pengetahuan Responden

\begin{tabular}{|l|c|c|}
\hline \multirow{2}{*}{ Keterangan } & \multicolumn{2}{|c|}{ Jumlah Responden } \\
\cline { 2 - 3 } & $\mathrm{N}$ & $\%$ \\
\hline Alur Rujukan & 12 & 20 \\
- Tahu & 48 & 80 \\
- Tidak Tahu & & \\
\hline Alur Pelayanan & 19 & 32 \\
- Tahu & 41 & 68 \\
- Tidak Tahu & & \\
\hline Kriteria Penyakit & 17 & 28 \\
Gawat Darurat & 43 & 72 \\
- Tahu & & \\
- Tidak Tahu & 29 & 48 \\
\hline Hak dan Kewajiban & 31 & 52 \\
- Tahu & \\
- Tidak Tahu &
\end{tabular}

Sumber: data primer diolah, 2017 
Kunjungan ke IGD dilakukan terbanyak pada jam 12.00 keatas sebanyak $65 \%$. Kunjungan diatas jam 12.00 pada hari senin, rabu dan kamis karena jumlah kunjungan banyak sehingga sering pasien datang di rawat jalan namun loket sudah tutup sehingga pasien diarahkn ke IGD. Adapun responden yang mengetahui alur rujukan hanya 20\%, yang mengetahui alur pelayanan ada $32 \%$ dan responden yang mengetahui kriteria gawat darurat hanya $28 \%$.responden yang mengetahui hak dan kewajiban ada $48 \%$.

\section{b. Wawancara dengan Kepala Bidang Pelayanan Medik}

Kepala Bidang Pelayanan Medik adalah pejabat esseleon IIIb yang bertanggungjawab kepada direktur dan menjalankan tugas dibidang pelayanan medik, penunjang pelayanan baik penunjang meik dan penunjang non medik. Unit dan Instalasi dibawah bidang pelayanan medik adalah : instalasi rawat jalan, instalasi rawat inap,instalasi gawat darurat, instalasi kamar bedah, instalasi CSSD, instalasi farmasi, instalasi pemeliharaan sarana rumah sakit, unit laboratorium, unit radiologi, unit gizi dan unit fisioterapi.

Dari hasil wawancara peneliti, disampaikan oleh Kepala Bidang Pelayanan Medik bahwa IGD merupakan salah satu pintu masuk pasien atau penggunjung lain telah memberikan pelayanan selama 24 jam dalam sehari dan tujuh hari dalam seminggu. IGD RSUD tidak pernah menolak pasien karena itu amanat peraturan perundangundangan dan tidak pernah meminta uang muka. Sering pasien datang datang dalam kondisi tidak sadar dan tanpa keluarga, tetap dilayani dan dikoordinasikan dengan dinas sosial agar dapat diterbitkan surat keterangan sebagai orang terlantar.

\section{c. Wawancara dengan Kepala Ruangan IGD}

Peneliti mendapatkan keterangandari Kepala Ruangan IGD mengenai alur rujukan bahwa saat pasien peserta JKN datang ke IGD banyak yang tidak membawa surat rujukan dari puskesmas bahkan menolak ditangani di rawat jalan. Daripada kami dituduh menolak pasien BPJS, maka kami tetap memberikan pelayanan sesuai standar. Terkait surat rujukan dapat diurus dikemudian hari setelah pasien dipindahkan pada ruang perawatan. Pasien datang langsung ke IGD tanpa rujukan dengan berbagai alasan. Padahal menurut peraturan yang ada, pasien BPJS harus datang pertama kali ke faskes tingkat pertama, jika memang tidak bisa di tangani faskes tingkat pertama maka pasien akan di rujuk ke faskes tingkat dua atau FKRTL.

Menurut Kepala Ruangan yang menyatakan bahwa Pasien peserta BPJS yang datang disepanjang bulan September adalah kebanyakan menderita Febris, ISPA dan Persalinan". Jika dilihat dari tingkat keparahan penyakit maka kondisi pasien tersebut tidak termasuk kategori gawat darurat. Hasil wawancara dengan Kepala Ruangan IGD menjelaskan bahwa ada tiga perawat yang tidak pernah sama sekali mengikuti pelatihan gawat darurat, sedangkan yang lainnya sudah mengikuti. Akan tetapi serifikatnya banyak sudah habis masa berlakunya. Kepala Ruangan IGD berpendapat bahwa dokter dan perawat yang belum memenuhi persyaratan tersebut karena penyelenggaraan pelatihan gawat darurat yang belum tersedia dan jarak yang tidak dapat dijangkau oleh tenaga kesehatan. Kepala Ruangan IGD juga berpendapat bahwa banyak petugas yang belum memiliki pelatihan yang diwajibkan, akan tetapi sudah ada rencana pengembangan agar pelatihan kegawat daruratan dilakukan pada RSUD. Dokter Jaga IGD mengemukan hambatan terkait SDM terletak pada jumlah tenaga dokter yang masih kurang. 


\section{d. Wawancara dengan Kepala Unit Jaminan Kesehatan Terpadu RSUD RAPB}

Terkait tugas dan fungsi Unit Jaminan Kesehatan Terpadu, oleh Kepala Unit dikatakan bahwa tugas unit ini adalah untuk membantu mengelola proses pelayanan administrasi pelayanan peserta JKN di RSUD. Tugas lain adalah melakukan pengumpulan berkas klaim dari semua ruang lalu mengelola sesuai aturan BPJS selanjutnya kami juga melakukan konfirmasi atau feedback dan audit dari BPJS. Dan yang tak kalah pentingnya adalah melakukan pengendalian.

Dalam menjalankan tugas dan fungsinya, Unit UJKT sering dihadapkan dengan masalah klaim yang belum sesuai pagu INA CBG's seperti klaim dari IGD masih merugi. Hal ini disebabkan oleh dokter IGD belum bekerja secara efisien dalam mengendalikan pemeriksaan dan pemberian obat kepada pasien paserta JKN. Walaupun semua klaim dibayarkan namun pendapatan rumah sakit dari IGD tetap rugi artinya bahwa karena pagu INA CBG's relatif kecil sehingga jumlah pemakaian obat dan bahan habis pakai juga jasa tindakan yang diberikan tidak sesuai.Salah satu fungsi unit UJKT adalah untuk melayani keluhan pasien peserta JKN, hal ini seperti yang disampaikan oleh Kepala Unit UJKT bahwa keluhan peserta JKN akan segera ditindaklanjuti dan diteruskan ke bidang-bidang yang berkompeten. Kegiatan ini dilaksanakan bersama-sama dengan humas RSUD Ratu Aji Putri Botung.

\section{e. Wawancara dengan dokter jaga IGD}

KMK Nomor 856/Menkes/SK/IX/2009 tentang Instalasi Gawat Darurat Rumah Sakit belum banyak diketahui oleh dokter jaga IGD sebagaimana yang dikatakan oleh salah seorang dokter IGD bahwa pedoman pelaksanaan pelayanan di IGD sesuai KMK Nomor 856/Menkes/SK/IX/2009, belum sepenuhnya saya pahami juga beberapa teman-teman dokter. Bahwa isi dari peraturan ini belum sepenuhnya bisa dijalankan karena terkait sarana/prasarana juga SDM. Jumlah SDM dokter yang kurang merupakan suatu penyebab mutu pelayanan di IGD kurang optimal karena dokter jaga IGD bekerja dengan merangkap sebagai dokter jaga ruang rawat inap.

Dalam menegakkan diagnosis gawat darurat, dokter telah mengikuti SPO yang berlaku di IGD termasuk diantaranya SPO triase. Jika pasien yang datang dalam kondisi sadar maka akan dilakukan perkenalan singkat oleh dokter dan dilanjutkan dengan anamnesa singkat untuk mengggali informasi terkait gangguan kesehatan yang dialami oleh pasien. Dokter kemudian akan melakukan pemeriksaan fisik dan jika diperlukan maka dokter akan melakukan pemeriksaan penunjang untuk mendukung kearah diagnosa yang diduga. Sementara menunggu hasil pemeriksaan penunjang maka dokter akan melakukan tindakan yang penting dan perlu sesuai kebutuhan medis pasien. Sebelum dilakukan tindakan maka dokter akan memberikan informasi kepada pasien tentang penyaitnya dan rencana tindakan yang akan dilakukan. Setelah pasien paham apa yang dilelaskan oleh dokter maka pasien harus menandatangani lembar informed consent.Selanjutnya dijelaskan oleh dokter jaga bahwa pada pasien-pasien yang datang dalam kondisi tidak sadar maka dokter IGD akan langsung melakukan intervensi setelah ada tindakan untuk penegakkan diagnosis awal. Dengan keterbatasan yang ada kami tetap berupaya memberikan pelayanan yang terbaik. Permasalahan sering muncul jika pasien datang adalah pasien tidak sadar dan hanya diantar oleh polisi atau orang yang menemukannya dijalan. Tanpa identitas yang jelas juga jaminan yang jelas. Untuk masalah ini kami menyerahkan kepada pihak manajemen. 


\section{f. Wawancara dengan paramedis IGD}

Alur pasien masuk dan keluar rumah sakit adalah suatu alur sejak pasien datang ke rumah sakit, menerima berbagai pelayanan rumah sakit, sampai pasien meninggalkan rumah sakit. Alur harus dilengkapi dengan petunjuk-petunjuk yang jelas, mudah terbaca dari jauh dan mudah terbaca pada malam hari. Kejelasan petunjuk arah dan lokasi diperlukan karena pasien maupun keluarganya sering kali mengalami kecemasan dan emosi yang labil. Hasil wawancara dengan petugas IGD mengatakan bahwa alur pelayanan belum ada dipajang diarea IGD sedangkan petunuk arah sudah ada namun perlu ditambah dan hurufnya perlu diperbesar agar pasien dapat melihat dengan jelas. Papan yang berisi hak pasien khusus di IGD belum dipasang.

Tenaga Kesehatan di Ruang IGD merekomendasikan, jika pada pagi hari pasien diarahkan untuk datang ke BPJS Center kemudian melakukan pendaftaran di loket IGD, dan apabila pada sore hari, pasien diarahkan untuk terlebih dahulu mendaftar pada loket IGD, pernyataan ini terlihat bahwa petugas IGD juga kurang memahami alur pelayanan pasien peserta BPJS yang seharusnya pada jam kunjungan pagi hari seharusnya tetap diarahkan untuk berobat ke klinik rawat jalan bagi pasien yang bukan kasus gawat darurat. Hal ini terjadi karena beberapa hal seperti: pasien enggan mengantri di klinik rawat jalan yang banyak pasien, pasien mau seenaknya datang dan membawa bawa nama pejabat teras kabupaten. Pihak rumah sakit menghadapi kendala seperti ini karena para pejabat di kabupaten tidak dengan bijaksana mendidik masyarakat untuk dengan tertib menjalankan budaya antri. "Sudah sering kami dimarahi oleh pasien, mereka mengatakan bahwa untuk apa bayar iuran kalau akhirnya disuruh bayar juga. Pasien yang pendidikannya rendah justru lebih kooperatif dibanding dengan pasien yang berpendidikan tinggi. PNS yang jelas-jelas ada sekolahnya malah yang paling sering marah-marah ketika dinyatakan sebagai pasien umum. Pasien-pasien ini ada yang taat saja dan bayar di kasir tapi ada juga yang langsung pulang.

\section{g. Wawancara dengan Kepala Kantor BPJS Kabupaten Penajam Paser Utara}

Hasil wawancara dengan Kepala Kantor BPJS RSUD Ratu Aji Putri Botung menjelaskan untuk pelayanan IGD yang tidak sesuai dengan ketentuan maka pihak BPJS akan melakukan koordinasi dengan RSUD agar pelayanan yang diberikan dapat berjalan sesuai dengan regulasi.

\section{h. Wawancara dengan Kepala Badan Perencanaan Pembangunan, Penelitian dan Pengembangan Kabupaten Penajam Paser Utara}

Wawancara singkat dengan Kepala Badan Pembangunan,Penelitian dan Pengembangan Kabupaten Penajam Paser Utara menyatakan bahwa, kami menyadari bahwa kebutuhan akan pelayanan kesehatan yang bermutu sangat dipengaruhi oleh ketersediaan anggaran pemerintah daerah namun pada kondisi saat ini dimana besaran anggaran daerah dipengaruhi oleh dana perimbangan sektor migas antara pemerintah pusat dan daerah yang menurun setiap tahunnya maka mau tidak mau suka tidak suka seluruh Satuan Kerja Perangkat Daerah di kabupaten ini mengalami imbas pengurangan anggaran belanja. Pendapatan yang bersumber dari pendapatan asli daerah tidak mampu membiayai kebutuhan pemerintah daerah karena masih sangat sedikit PAD kabupaten ini. 


\section{i. Wawancara dengan Kepala Dinas Kesehatan}

Dinas Kesehatan memiliki tugas untuk melakukan pengawasan, monitoring dan pembinaan terhadap rumah sakit bersama-sama dengan BPJS hal ini berdasarkan ketentuan Permenkes No. 28 Tahun 2014 tentang Pedoman Pelaksanaan Program Jaminan Kesehatan Nasional. Dinas Kesehatan memiliki upaya terkait adanya Puskesmas yang merujuk pasien yang seharusnya masih bisa ditangani pada Puskesmas yakni, menegaskan bahwa 155 penyakit non spesifik tidak harus melakukan rujukan pasien, kecuali Puskesmas tidak memiliki sarana dan prasarana serta keterbatasan sumber daya manusia.

Terkait hal ini Kepala Dinas Kesehatan menyatakan bahwa, pengawasan yang dilakukan lebih difokuskan pada puskesmas yang memberikan pelayanan tingkat pertama. Pihak Dinas Kesehatan senantiasa mengingatkan dan memantau kegiatan di puskesmas baik melalui pengamatan langsung ataupun melalui laporan bulanan yang disetor ke Dinas Kesehatan. Kendala utama adalah tenaga dokter yang kurang sarana yang belum memadai sehingga seringkali pasien harus dirujuk ke rumah sakit yang seharusnya bisa ditanagani oleh puskesmas.

\section{B. Pembahasan}

1. Pelaksanaan Ketentuan Pelayanan Gawat Darurat bagi Peserta JKN di IGD RSUD Ratu Aji Putri Botung

a. Undang-Undang Republik Indonesia Nomor 36 Tahun 2009 tentang Kesehatan Pada Pasal 15 dikatakan bahwa, pemerintah bertanggung jawab atas ketersediaan lingkungan, tatanan, fasilitas kesehatan baik fisik maupun sosial bagi masyarakat untuk mencapai derajat kesehatan yang setinggi-tingginya.Di Kabupaten Penajam Paser Utara, RSUD Ratu Aji merupakan satu-satunya rumah sakit yang telah berdiri sejak tahun 2007.Kontribusi pemerintah daerah dalam menyediakan fasilitas pelayanan kesehatan harus lebih ditingkatkan dengan cara menjadikan kebutuhan pelayanan kesehatan sebagai salah satu prioritas bukan hanya sebagai misi pemerintah yang dicacat diatas kertas. Keberpihakan pemda dalam kebijakan anggaran belum sepenuhnya tercermin dalam Dokumen Pelaksanaan Anggaran (DPA) tahun 2017. Bahwa ada masalah dalam jumlah pembagian dana bagi hasil migas, tidak menjadikan alasan untuk mengabaikan skala prioritas bidang kesehatan.

b. Undang-Undang Republik Indonesia Nomor 44 Tahun 2009 tentang Rumah Sakit

Dalam Pasal 29 (c)dinyatakan bahwa salah satu kewajiban rumah sakit adalah memberikan pelayanan gawat darurat kepada pasien sesuai dengan kemampuan pelayanannya. Amanah ini mewajibkan setiap rumah sakit yang ada di Indonesia termasuk RSUD Ratu Aji Putri Botung untuk memberikan pelayanan gawat darurat sesuai dengan kemampuannya dalam hal ini sesuai dengan ketersediaan sarana, fasilitas dan SDM yang ada. Karena merupakan rumah sakit tipe C, RSUD Ratu Aji Putri Botung termasuk IGD level II yang memberikan pelayanan diagnosis dan pelayanan permasalahan $A B C$, penilaian disability,penggunaan obat namun belum mempunyai fasilitas bedah cito.Selanjutnya dalam Pasal 29 (f) rumah sakit melaksanakan fungsi sosial antara lain dengan memberikan fasilitas pelayanan pasien tidak mampu/miskin, pelayanan gawat darurat tanpa uang muka, ambulan 
gratis, pelayanan korban bencana dan kejadian luar biasa, atau bakti sosial bagi misi kemanusiaan. RSUD Ratu Aji Putri Botung telah melakukan pelayanan kepada peserta JKN baik PBI dan non PBI tanpa meminta uang muka terutama pada kasus gawat darurat. pelayanan ambulan sebagai salah satu manfaat non medis pada pasien JKN telah diberikan sesuai peruntukannya.

c. Undang-Undang Republik Indonesia Nomor 24 Tahun 2011 tentang Badan

Penyelenggara Jaminan Sosial

Pelayanan medis bagi pasien peserta JKN telah diberikan oleh IGD RSUD Ratu Aji Putri Botung sesuai standar pelayanan. Pelayanan untuk ambulan juga telah diberikan pelayanan sesuai pertaturan dimana pasien yang menggunakan ambulan tidak dimintai pembayaran. Rumah sakit nanti yang akan melakukan klaim ke BPJS. Hal ini dengan jelas menggambarkan bahwa pihak rumah sakit telah memberikan manfaat peserta JKN yaitu pelayanan ambulan.Larangan penolakan pasien JKN Pasal 47 ayat (1) Peraturan Badan Penyelenggara Jaminan Sosial Kesehatan Nomor 1 Tahun 2014 tentang Penyelenggaraan Jaminan Kesehatan (Peraturan BPJS 1/2014) menyebutkan, bahwa setiap peserta jaminan kesehatan berhak memperoleh pelayanan kesehatan yang mencakup pelayanan promotif, preventif, kuratif dan rehabilitatif termasuk pelayanan obat dan bahan medis habis pakai sesuai dengan kebutuhan medis yang diperlukan. Pasal 63 ayat (4) Peraturan BPJS 1/2014 menyebutkan bahwa fasilitas kesehatan yang tidak bekerja sama dengan BPJS Kesehatan harus segera merujuk ke fasilitas kesehatan yang bekerja sama dengan BPJS Kesehatan setelah keadaan daruratnya teratasi dan pasien dalam kondisi dapat dipindahkan.

\section{d. Peraturan Presiden Republik Indonesia Nomor 12 Tahun 2013 tentang Jaminan} kesehatan

Dalam peraturan tentang prosedur pelayanan dikatakan bahwa peserta yang memerlukan pelayanan kesehatan harus pertama-tama memperoleh pelayanan kesehatan pada faskes tingkat pertama. Bila memerlukan pelayanan kesehatan tingkat lanjutan maka harus dilakukan melalui mekanisme rujukan kecuali dalam kondisi gawat darurat. Dalam pelaksanaanya masih banyak masyarakat yang datang di IGD rumah sakit tidak dalam kondisi gawat darurat dan tanpa mebawa surat rujukan. Masyarakat dalam hal ini peserta JKN tidak paham benar tentang alur pelayanan dan alur rujukan seperti dalam hasil temuan peneliti tentang pengetahuan responden.

e. Peraturan Badan Penyelenggaraan Jaminan Sosial Kesehatan Nomor 1 Tahun

2014 tentang Penyelenggara Jaminan Kesehatan

Peserta JKN masih ada yang merasa telah membayar premi setiap bulan tapi ditolak oleh IGD. Pada kenyataannnya bahwa petugas IGD tidak menolak namun tetap melayani. Namun berdasarakan Pasal 25 huruf a Peraturan Presiden Nomor 19 Tahun 2016 Tentang Perubahan Kedua Atas Peraturan Presiden Nomor 12 Tahun 2013 Tentang Jaminan Kesehatan bahwa pelayanan yang tidak dijamin adalah "pelayanan kesehatan yang dilakukan tanpa melalui prosedur sebagaimana diatur dalam peraturan yang berlaku", maka biaya pelayanan pasien tidak dapat dijamin oleh BPJS Kesehatan. Pengetahuan pasien pserta JKN merupakan suatu hal yang penting diperhatikan agar dalam pelayanan kesehatan di era JKN dapat berlangsung dengan aman,lancar dan berdayaguna.Jika diperhatikan maka 
pelaksanaan sosialisasi adalah pilihan bagi RSUD Ratu Aji Putri Betong adalah solusi yang cepat,tepat dan murah seharusnya dilakukan. Demikian juga BPJS harus senantiasa menjelaskan beberapa ketentuan dengan bahasa yang mudah dimengerti oleh peserta.

f. Keputusan Menteri Kesehatan Nomor 856/Menkes/SK/IX/2009 tentang Standar Instalasi Gawat Darurat Rumah Sakit.

1) Standar yang telah terpenuhi

a) Pelayanan kesehatan yang diberikan di Instalasi Gawat Darurat (IGD) adalah pelayanan 24 jam sehari dan tujuh hari dalam seminggu.

b) RSUD Ratu Aji Putri Botung tidak meminta uang muka pada saat menerima pasien yang dilayani di IGD dan tidak menolak pasien yang datang di IGD terutama pasien dengan kegawatdaruratan.

c) Standar Pelayanan Minimal tahun 2016, IGD RSUD telah mampu memberikan penanganan pasien di IGD tidak sampai 5 menit setelah pasien tiba di IGD. Hal ini sangat penting karena kecepatan penangan pasien akan berimbas kepada hasil penatalaksanaan kegawatdaruratan. Semakin cepat ditangani semakin baik pula hasil atau proses penyembuhan atau keselamatan jiwa pasien.

2) Standar yang belum terpenuhi

a) Struktur organisasi, belum mencerminkan keterlibatan profesi lain dan multidisiplin. Hal terjadi dikarenakan beberapa fasilitas masih berada diluar gedung IGD seperti radiologi, laboratorium dan belum adamya kamar bedah cito sehingga kegiatan di IGD di dominasi oleh dokter umum dan paramedis saja;

b) RSUD Ratu Aji Putri Betong adalah rumah sakit tipe $\mathrm{C}$ maka jenis pelayanan termasuk dalan level IV dengan kemampuan level II;

c) Tindakan pembedahan cito belum pernah dilakukan, dikarenakan belum ada faslitas kamar bedah di IGD. Belum tersedianya satu tindakan kegawatdaruratan di RSUD tidak dapat dikatakan tidak memenuhi ketentuan keputusan menteri tersebut, karena berdasarkan Pasal 29 ayat 9 butir c Undang-Undang Nomor 44 Tahun 2009 tentang Rumah Sakit dikatakan bahwa rumah sakit "memberikan pelayanan gawat darurat kepada pasien sesuai dengan kemampuan pelayanannya";

d) Pelatihan GELS (General Emergency Life Saving), ada seorang dokter yang tidak ada yang memiliki pelatihan GELS dan terdapat tiga (3) orang perawat yang tidak memiliki setifikat ACLS (Advance Cardiac Life Support);

e) Ruang penerimaan, belum dilengkapi dengan ruang informasi dan keamanan yang menetap;

f) Ruang tindakan masih bergabung yaitu tindakan anak dan kebidanan;

g) Ruang dekontaminasi tidak ada karena lokasi RS jauh dari industry;

h) Ruang operasi tidak bergabung dengan IGD, pelayanan operasi dilakukan dikamar bedah sentral;

i) Ruang High Care Unit (HCU) belum ada;

j) Jumlah tenaga dokter dan paramedis yang masih kurang. 


\section{g. Standar Prosedur Operasional di IGD RSUD Ratu Aji Putri Botung}

Standar prosedur operasional yang ada di IGD terdiri dari SPO manajerial sebanyak 22 standar, SPO lintas instalasi sebanyak 30 standar. SPO pemeliharaan alat elektromedik sebanyak delapan standardan SPO tindakan medik sebanyak 140 standar. SPO yang berhubungan dengan pelayanan bagi peserta JKN adalah SPO Pendaftaran pasien BPJS, SPO penerimaan pasien baru, SPO Triage, SPO menerima pasien rujukan dan SPO merujuk pasien. Untuk mengelompokan pasien gawatdarurat, IGD RSUD menggunakan sistem triage. Triage adalah seleksi pasien sesuai tingkat kegawat daruratan sehingga pasien terseleksi dalam mendapatkan pertolongan sesuai dengan tingkat kegawatdaruratannya.Triage di RSUD Ratu Aji Putri Botung menggunakan system labeling warna, pasien ditentukan apakah gawat darurat, gawat tidak darurat, atau darurat tidak gawat atau tidak gawat tidak darurat.

2. Pelaksanaan KMK Nomor $856 /$ Menkes/SK/IX/2009 Tentang Standar Instalasi Gawat Darurat Rumah Sakit di IGD RSUD Ratu Aji Putri Botung

Untuk mengetahui sejauh mana efektivitas KMK Nomor 856/Menkes/SK/IX/2009 Tentang Standar Instalasi Gawat Darurat di Rumah Sakit, teori yang dikemukakan oleh Lawrence Meir Friedman seorang ahli sosiologi hukum Stanford University bahwa untuk mengetahui efektivitas dari hukum dan implementasinya dalam masyarakat perlu dilihat dari tiga aspek atau unsur yaitu:

a. Struktur (Legal Structure)

Pada pelaksanaan KMK/Menkes/SK/IX/2009 Tentang Standar Instalasi Gawat Darurat di Rumah Sakit, belum dilaksanakan secara utuh sampai lewat batas waktu yang disyaratkan dalam keputusan menteri kesehatan ini. Peraturan ini dibuat ditahun 2009 dan batas waktu pelaksanaan adalah lima tahun setelah keputusan ini dibuat. Ditahun 2017 beberapa ketetatapan tidak dipenuhi oleh RSUD Ratu Aji Putri Botung.

Dari kenyataan ini belum juga ada evaluasi dan pemberian sanksi karena sesungguhnya didalam keputusan menteri ini tidak mengatur sanksi didalamnya. Hanya dikatakan bahwa pencapaian dan penerapan Standar Instalasi Gawat Darurat Rumah Sakit dilaksanakan secara bertahap berdasarkan pada analisis kemampuan dan potensi daerah. Hal ini dapat dimaknai bahwa ada toleransi untuk untuk menjalankan ketentuan ini berdasarkan kemampuan dan potensi daerah dalam hal ini keuangan daerah.

Jika ketentuan tentang sanksi pada peraturan ini tidak ada maka, efektivitas hukum kurang berfungsi. Bahwa menurut teori efektivitas hukum Hans Kelsen difokuskan pada subjek dan sanksi. Subjek yang melaksanakannya, yaitu orang-orang atau badan hukum. Orang-orang tersebut harus melaksanakan hukum sesuai dengan bunyinya norma hukum. Sanksi merupakan inti dari penegakan hukum. Karena tidak ada sanksi yang berfungsi untuk menekan atau sebagai daya paksa untuk menjalankan aturan hukum maka tidak menimbulkan suatu keharusan yang mutlak untuk menjalankan aturan hukum itu. Sanksi dalam hal ini adalah sanksi administrasi. 
b. Substansi (Legal Substance)

Substansi dari KMK 856/Menkes/SK/IX/2009 tentang Standar IGD Rumah Sakit adalah bahwa Standar Instalasi Gawat Darurat (IGD) Rumah Sakit agar digunakan sebagai acuan bagi tenaga kesehatan dan penyelenggara rumah sakit dalam memberikan pelayanan gawat darurat di rumah sakit. Bahwa Dinas Kesehatan Provinsi dan Dinas Kesehatan Kabupaten/ Kota melakukan pembinaan dan pengawasan pelaksanaan Standar Instalasi Gawat Darurat ( IGD ) Rumah Sakit dengan melibatkan organisasi profesi terkait sesuai dengan tugas dan fungsinya masing- masing.

Pada pelaksanaannya bahwa Keputusan Menteri Kesehatan Nomor 856/Menkes/SK/IX/2009 ini telah menjadi acuan IGD RSUD Ratu Aji Putri Botung sebagai standar dalam melaksanakan pelayanan di IGD namun belum dilaksanakan secara menyeluruh sampai batas waktu yang ditetapkan oleh ketentuan ini.Kendala pada pelaksanaan aturan ini terletak pada pemahaman tentang tugas dan fungsi kelembagaan Dinas Kesehatan sebagai perpanjangan tangan pemerintah daerah dalam mengawasi pelaksanaan pelayanan kesehatan diwilyah kerja kabupaten Penajam Paser Utara.

c. Budaya Hukum (Legal Culture)

Dalam pelaksanaan KMK/Menkes/SK/IX/2009 Tentang Standar IGD Rumah Sakit, yang menjadi masyarakat pelaksana hukum adalah Rumah Sakit dan seluruh SDM yang ada didalamnya. Bahwa kultur hukum eksternal disini memperlihatkan bahwa kesadaran untuk menjalankan peraturan perundang-undangan ini masih rendah. Hal ini dibuktikan dengan beberapa persyaratan IGD belum terlaksana dan terpenuhi sampai dibatas waktu yang telah ditetapkan. Kendala yang menjadi hambatan pelaksanaan keputusan menteri ini terdapat pada pemenuhan sarana,prasarana, fasilitas dan SDM baik kualitas dan kuantitas.

3. Hambatan-hambatan dalam pelaksanaan KMK Nomor 856/Menkes/SK/IX/2009 Tentang Standar Instalasi Gawat Darurat di Rumah Sakit di IGD RSUD Ratu Aji Putri Botung

a. Aspek yuridis

Dari aspek yuridis terdapat hambatan yaitu tidak adanya peraturan ditingkat daerah baik propinsi dan kabupaten yang mengatur pelaksanaan kegawatdaruratan baik secara umum didalam Sistem Kesehatan Daerah atau secara terpisah khusus mengatur tentang kegawatdaruratan di fasilitas kesehatan dan pada saat bencana. Dari aspek yuridis KMK Nomor 856/Menkes/SK/IX/2009 tentang Standar IGD Rumah Sakit, tidak mengatur sanksi bagi penyelenggara pelayanan gawat darurat di daerah juga sanksi bagi pemerintah daerah.

b. Aspek sarana prasarana

Aspek saran prasarana menjadi hambatan dalam pelayanan kesehtan terlihat dari hasil pengecekan dilapangan bahwa masih ada fasilitas pelaksanaan dari keputusan menteri ini yang belum terpenuhi sengga beberapa SPO yang ada belum dapat dilaksanakan secara optimal. 


\section{c. Aspek anggaran}

Aspek anggaran memegang porsi yang cukup besar sebaga penghambat berlangsungnya pelayanan kesehatan yang optimal di IGD RSUD Ratu Aji Putri Botung. Diperlukan perhatian khusus oleh pemda untuk mengalokasikan anggaran yang sesuai kebutuhan rumah sakit secara umum dan IGD secara khusus agar hakhak pasien juga hak rumah sakit selaku penyelenggara pelayanan kesehatan dapat terpenuhi sesuai amanat peratauran perundang-undangan.

d. Aspek sumber daya manusia

Aspek SDM juga merupakan penghambat terlaksananya peraturan menteri ini. Kuantitas dari dokter yang bertugas di IGD menghambat pemberian pelayanan yang bermutu bagi pasien peserta JKN. Kurangnya dokter spesialis yang tinggal dekat dengan rumah sakit menjadi penghambat pelayanan yang paripurna dalam menjawab pemenuhan hak pasien di IGD. Aspek kualitas dokter jaga IGD juga menjadi penghambat pelayanan kesehatan yang bermutu. Dokter di IGD masih ada yang belum sepenuhnya memahami diagnosis gawat darurat. hal ini berimplikasi pada pelayanan dimana terjadi penegakan diagnosis menjadi kurang tepat dan pemeriksaan penunjang menjadi berlebihan dan tidak sesuai lagi dengan SPO. Implikasi lain yaitu pemberian obat menjadi berlebihan. Kenyataan ini terlihat dari klaim yag diajukan oleh IGD sebagian tidak dibayarkan sesuai dengan jumlah klaim yang diajukan oleh rumah sakit kepada pihak BPJS.

e. Aspek pengetahuan masyarakat

Aspek pengetahuan msyarakat menjadi salah satu hambatan karena dengan penegetahuan yang kurang maka proses pelayanan menjadi terhambat dan kurang bermutu. Terhambat dari segi waktu pelayanan yang menjadi panjang dan oleh peserta dirasakan menjadi berbelit-belit padahal hanya karena pengetahuan peserta yang kurang.

\section{KESIMPULAN DAN SARAN}

\section{A. KESIMPULAN}

1. Pelaksanaan Ketentuan Pelayanan Gawat Darurat bagi Peserta JKN di Instalasi Gawat Darurat

a. Seorang dokter dalam menjalankan profesinya mendapatkan perlindungan hukum sepanjang dokter dalam melakukan pekerjaannya tetap berpedoman pada standar profesi dan standar prosedur oprasional. Perlindungan hukum ini menjadi tanggung jawab institusi atau badan hukum yang mempekerjakan tenaga dokter tersebut.

b. Kontribusi pemerintah daerah dalam menyediakan fasilitas pelayanan kesehatan harus lebih ditingkatkan dengan cara menjadikan kebutuhan pelayanan kesehatan sebagai salah satu prioritas bukan hanya sebagai misi pemerintah yang dicacat diatas kertas. Keberpihakan pemda dalam kebijakan anggaran belum sepenuhnya tercermin dalam Dokumen Pelaksanaan Anggaran (DPA) tahun 2017.

c. RSUD Ratu Aji Putri Botung telah melakukan pelayanan kepada peserta JKN baik $\mathrm{PBI}$ dan non $\mathrm{PBI}$ tanpa meminta uang muka terutama pada kasus gawat darurat. 
pelayanan ambulan sebagai salah satu manfaat non medis pada pasien JKN telah diberikan sesuai peruntukannya.

d. Prosedur pelayanan peserta JKN yang memerlukan pelayanan kesehatan harus pertama-tama memperoleh pelayanan kesehatan pada faskes tingkat pertama. Bila memerlukan pelayanan kesehatan tingkat lanjutan maka harus dilakukan melalui mekanisme rujukan kecuali dalam kondisi gawat darurat.

e. Masyarakat dalam hal ini peserta JKN tidak paham benar tentang alur pelayanan dan alur rujukan. Pengetahuan pasien peserta JKN merupakan suatu hal yang penting diperhatikan agar dalam pelayanan kesehatan di era JKN dapat berlangsung dengan aman,lancar dan berdayaguna.

f. Pemberian pelayanan gawat darurat di IGD RSUD Ratu Aji Putri Botung yang telah bekerja sama dengan BPJS Kesehatan tidak pernah menarik biaya pelayanan kesehatan kepada peserta JKN.

g. Standar prosedur operasional yang ada di IGD terdiri dari SPO manajerial sebanyak 22 standar, SPO lintas instalasi sebanyak 30 standar. SPO pemeliharaan alat elektromedik sebanyak delapan standardan SPO tindakan medik sebanyak 140 standar.Pelaksanaan SPO di IGD RSUD Ratu Aji Putri Botung telah dilakukan sebagian dan belum pernah ada evaluasi pelaksanaanya.

2. Pelaksanaan Keputusan Menteri Kesehatan Nomor 856/Menkes/SK/IX/2009 tentang Standar Instalasi Gawat Darurat (IGD) Rumah Sakit

Dapat disimpulkan KMK Nomor 856/Menkes/SK/IX/2009 tentang Standar IGD Rumah Sakit termasuk tidak efektif walaupun bahasa dalam keputusan menteri ini mudah dipahami namun tidak adanya sanksi yang diatur didalamnya maka tidak adanya unsur memaksa dan mendesak dari suatu peraturan menjadikannya tidak efektif. Tidak adanya evaluasi dari pelaksanaan keputusan menteri ini menjadikan pelaksanaan keputusan menteri ini dijalankan dengan seadanya sesuai kondisi yang mempengaruhinya.

3. Hambatan-hambatan dalam pelaksanaan Keputusan Menteri Kesehatan Nomor 856/Menkes/SK/IX/2009 tentang Standar Instalasi Gawat Darurat di Rumah Sakit

a. Aspek yuridis

1) Struktur Hukum

Tidak adanya peraturan ditingkat daerah baik Propinsi dan Kabupaten yang mengatur pelaksanaan kegawatdaruratan baik secara umum didalam Peraturan Daerah tentang Sistem Kesehatan Daerah atau secara terpisah khusus mengatur tentang kegawatdaruratan di fasilitas kesehatan dan pada saat bencana.

2) Substansi Hukum

Dari aspek yuridis KMK Nomor 856/Menkes/SK/IX/2009 tentang Standar IGD Rumah Sakit, tidak mengatur sanksi bagi penyelenggara pelayanan gawat darurat di daerah juga sanksi bagi pemerintah daerah. 
3) Kultur/Budaya Hukum

a) Adanya kultur hukum yang masih rendah merupakan hambatan yang sangat merugikan bagi penyelenggaraan pelayanan kepada masyarakat.

b) Kurangnya sosialisasi mengenai peraturan-perundang-undangan di bidang kesehatan.

c) Pengawasan dan pembinaan dari pejabat struktural dalam menciptakan kultur hukum dilingkungan RSUD Ratu Aji Putri Botung, masih kurang memadai.

\section{b. Aspek sarana prasarana}

Aspek saran prasarana menjadi hambatan dalam pelayanan kesehatan terlihat dari hasil pengecekan dilapangan bahwa masih ada fasilitas yang dibutuhkan bagi pelaksanaan dari keputusan menteri ini yang belum terpenuhi sehingga berdampak pada beberapa SPO yang ada belum dapat dilaksanakan secara optimal. Sarana/prasarana dan fasilitas yang ada juga sudah banyak yang mulai rusak. Kegiatan pemeliharaan peralalatan, sarana dan prasarana juga terkendala pada anggaran yang tidak memadai bagi kegiatan pemeliharaan barang dan bangunan.

\section{c. Aspek anggaran}

Aspek anggaran memegang porsi yang cukup besar sebagai penghambat berlangsungnya pelayanan kesehatan yang optimal di IGD RSUD Ratu Aji Putri Botung. Diperlukan perhatian khusus oleh pemda untuk mengalokasikan anggaran yang sesuai kebutuhan rumah sakit secara umum dan IGD secara khusus agar hakhak pasien juga hak rumah sakit selaku penyelenggara pelayanan kesehatan dapat terpenuhi sesuai amanat peraturan perundang-undangan.

\section{d. Aspek sumber daya manusia}

Aspek SDM juga merupakan penghambat terlaksananya peraturan menteri ini. Kuantitas dari dokter yang bertugas di IGD menghambat pemberian pelayanan yang bermutu bagi pasien peserta JKN. Kurangnya dokter spesialis yang tinggal dekat dengan rumah sakit menjadi penghambat pelayanan yang paripurna dalam menjawab pemenuhan hak pasien di IGD. Aspek kualitas dokter jaga IGD juga menjadi penghambat pelayanan kesehatan yang bermutu. Dokter di IGD masih ada yang belum sepenuhnya memahami diagnosis gawat darurat. Hal ini berimplikasi pada pelayanan dimana terjadi penegakan diagnosis menjadi kurang tepat dan pemeriksaan penunjang menjadi berlebihan dan tidak sesuai lagi dengan SPO. Implikasi lain yaitu pemberian obat menjadi berlebihan. Kenyataan ini terlihat dari klaim yag diajukan oleh IGD sebagian tidak dibayarkan sesuai dengan jumlah klaim yang diajukan oleh rumah sakit kepada pihak BPJS.

\section{e. Aspek pengetahuan masyarakat}

Aspek pengetahuan masyarakat menjadi salah satu hambatan karena dengan pengetahuan yang kurang maka proses pelayanan menjadi terhambat dan kurang bermutu. Terhambat dari segi waktu pelayanan yang menjadi panjang dan oleh peserta dirasakan menjadi berbelit-belit padahal hanya karena pengetahuan peserta yang kurang. Sosialisasi yang telah dilakukan oleh BPJS telah dilakukan dengan intens,namun nampaknya masyarakat belum juga mampu dan mau mengakses informasi yang bermanfaat bagi dirinya sebagai peserta JKN. 


\section{B. SARAN}

1. Kementerian Kesehatan harus membuat peraturan yang mencantumkan sanksi bagi pelaksana dari perataran itu, agar suatu ketentuan perundang-undangan itu efektif dilaksanakan oleh masyarakat termasuk masyarakat pemberi pelayanan yaitu seluruh staf di rumah sakit maka pemerintah dalam hal ini Kementerian Kesehatan harus membuat peraturan yang mencantumkan sanksi bagi pelaksana dari perataran itu.

2. Pemerintah daerah harus membuat peraturan daerah terkait pelaksanaan pelayanan gawat darurat. Baik secara umum tentang Sisten Kesehatan Daerah atau secara terpisah dikhususkan tentang kegawatdaruratan di IGD atau pada saat kondisi ada bencana agar pelaksanaan di daerah memiliki peraturan dan perundangundangan yang disesuaikan dengan kondisi daerah.

3. Pemerintah dan pemerintah daerah harus melakukan pemberian alokasi dana yang rasional sesuai kebutuhan yang didasarkan pada peraturan perundang-undangan agar pelayanan kegawatdaruratan didaerah dapat terlaksana dengan baik sesuai dengan peraturan perundang-undangan yang ada.

4. RSUD Ratu Aji Putri Botung harus melakukan perencanaan kebutuhan sarana prasarana dan kebutuhan sumber daya manusia baik kuantitas dan kualitas yang ada di rumah sakit sesuai tipe rumah sakit. Kemudian melakukan advokasi kepada pemerintah daerah agar dapat terpenuhinya sarana/prasarana dan sumber daya manusia sesuai dengan standar yang diamanatkan oleh peraturan perundangundangan.

5. Instalasi Gawat Darurat, harus melakukan revisi dan evaluasi SPO sesuai dengan pertuntukannya dalam memberikan pelayanan di IGD agar didapatkan SPO yang benar sesuai dengan ketentuan peraturan di bidang kesehatan.

6. BPJS harus melakukan sosialisasi dan koordinasi tentang pelaksanaan JKN ditengah masyarakat dan di fasilitas kesehatan agar dapat meningkatkan pengetahuan masyarakat tentang JKN.

7. Dinas Kesehatan harus melakukan monitoring dan evaluasi sejauhmana pelaksanaan JKN apakah telah sesuai dengan peraturan yang ada dengan senantiasa turun kelapangan juga melakukan diskusi membedah masalah masalah yang muncul ditengah masyarakat dan faskes agar permasalahan yang muncul dapat ditindaklanjuti penyelesainnya dan pelaksanaan JKN dapat berjalan sesuai dengan ketentuan peraturan perundang-undangan yang ada.

8. Masyarakat, harus senantiasa meningkatkan pengetahuannya tentang peraturan sebagai peserta JK agar dalam menerima pelayanan di fasilitas kesehatan dapat menjalankannya dengan efektif dan efisien sesuai manfaat sebagai peserta JKN. 


\section{DAFTAR PUSTAKA}

Anonim, Panduan Praktik Tentang Kepersertaan yang Diselenggrakan Oleh BPJS Kesehatan Berdasarkan Regulasi yang sudah Terbit.

Moha Anugrah Aditya, 2016, Ekonomi Politik Kesehatan Indonesia: Refleksi Pemikiran dan Kebijakan Kesehatan, Jakarta: PT. Wahana Semesta Intermedia.

Anonim, 2015, Rencana Strategis Kementerian Kesehatan Tahun 2015-2019

Rosihan Adhani, 2016, Mengelola Rumah Sakit, Banjarmasin: Lambung Mangkurat University Press.

Amir llyas, Pertanggungjawaban Pidana Dokter dalam Malpraktik Medik di Rumah Sakit, Yogyakarta: Rangkang Educatio.

Abdulkadir Muhammad, 2004, Hukum dan Penelitian Hukum, Bandung: Citra Aditya Bakti.

Soejono Soekanto, 2015, Pengantar Penelitian Hukum, Jakarta: Penerbit Universitas Indonesia.

Amiruddin, 2006, Pengantar Metode Penelitian Hukum, Jakarta: PT Grafindo Persada.

Soerjono Soekanto dan Sri Mamudji, 2003, Penelitian Hukum Normatif, Suatu Tinjauan Singkat, Jakarta: PT. Raja Grafindo Persada.

Ronni Hanitijo Seomitro, 1994, Metodologi Penelitian Hukum dan Jurimetri, Jakarta: Ghalia Indonesia.

Abdul, Kadir Muhammad, 2004, Hukum dan Penelitian Hukum, Cet. Ke-1, Bandung: PT. Citra Aditya Bakti. 